Doc. dr. Muharem Štulanović

\title{
ANALITIČKA STUDIJA O HISTORIJSKOJ I PRAKTIČNOJ TRANSFORMACIJI ŠERIJATA U ŠERIJATSKE OBIČAJE I TRADICIJU (̌̌erijatska etnološka studija)
}

\section{Sažetak}

Kod muslimana naših krajeva desilo se da je u jednom historijskom periodu efikasno, konstantno sukcesivno prakticiranje, posebno obredoslovne grane Šerijata, uslovilo da u muslimanskom društvu nastanu mnogobrojni islamski, šerijatski običaji. Šerijat se jednostavno pretvorio u običaj (a'det) i kao takav uspio prilagoditi „,teškim vremenima" $i$ sačuvati od potpunog nestajanja iz pravne prakse. Naravno, nije to bio slučaj sa kompletnim sistemom Šerijata.

Tu se radi o tzv. Božijim hakkovima (dužnost prema Bogu) kao što su islamski ruknovi: šehadet, namaz, post, zekjat i hadždž.

$U$ literarnom narodnom stvaralaštvu, narodnom blagu, narodnim pjesmama, dosjetkama, mudrostima itd. imamo bilježenje, deskripciju $i$ verifikaciju tih običaja $i$ običajne prakse muslimana $u$ pojedinim mjestima BiH.

Pošto je Šerijat obaveznog karaktera za sljedbenike i pošto je vjera bit i svrha čovjekovog života kao što se razumije iz kur'anske norme Džine i ljude sam stvorio samo zato da bi mi se klanjali /EzZarijat:56/, onda se i običaji - u koje su se pretvorile $i$ transformisale mnogobrojne šerijatske norme tokom njegove historijske evolucije na našim prostorima - obavezno primjenjuju, poštuju i ne skrnave, kako konstatuje narodni pjesnik, ,, makar glava bila u pitanju”.

Islamski ummet, pravi muslimani znaju odgovor na pitanje svrhe života. Oni su shvatili filozofiju života, bit i svrhu postojanja na dunjaluku. Shvatili su vjeru i vrijednost vjere. Zato je njihova vjerska praksa bila toliko učestala i konstantna da je ušla u običaj i tradiciju o kojoj smo imali priliku saznati informaciju više $i$ okoristiti se time $i$ kroz ovaj rad.

Evidentno je da je od sedamdesetih godina 20. vijeka trend sekularizacije pravnih sistema muslimanskih zemalja zaustavljen. 
Zapaženo je interesovanje za reafirmisanje Šerijata, koji se iznova izučava, ne više samo kao historijski fenomen koji je bio i nestao nego kao pravni sistem interesantan i zanimljiv u predmetu savremenog uporednog prava.

Šerijat je kod muslimana sveobuhvatni način življenja. U općoj historiji prava zauzima mjesto jednog od najuticajnijih pravnih sistema uopće te uz anglosaksonsko i evropskokontinentalno pravo tretira se najznačajnijim izvorom pozitivnog prava savremenih nacionalnih država.

U vrijeme dominacije islamske zakonodavne i izvršne vlasti islam, tj. Šerijat primjenjivao se kao kompletan pravni sistem. Kako je slabila ta vlast i povlačila se, tako je slabila i primjena Šerijata da bi se svela i reducirala u krajnjoj konsekvenci samo na kodeks privatne i društvene vjerske etike. Dakle, Šerijat je imao u svojoj primjeni evolutivni put do svoje konačne transformacije u običaj i tradiciju.

U evolutivnoj praksi i procesu transformacije Šerijat je u BiH prošao nekoliko faza.

- U fazi osmanske zakonodavne i izvršne vlasti Šerijat je bio osnovni izvor pozitivnih propisa. U ovom vremenskom intervalu, kada se Šerijat konstantno primjenjivao kao pozitivni pravni sistem, nastali su i razvili se mnogobrojni šerijatski običaji.

- U vrijeme između dvaju svjetskih ratova oficijelna primjena Šrijata svodila se na praksu šerijatskih sudova inkorporiranih ograničenim ingerencijama $u$ aktualni pravni poredak.

- Na kraju tog historijskog evolutivnog procesa $\mathrm{u} \mathrm{BiH}$ dokidanjem šerijatskih sudova 1946. g. zvanično je dokinut i ostatak šerijatskog zakonodavstva u oficijelnoj, zvaničnoj primjeni.

- Daljnja egzistencija Šerijata, do sedamdesetih godina prošloga vijeka, vezuje se samo za njegovu transformisanu verziju u moralno etički kodeks, islamske ãdete, običaj i tradiciju a njegovo tumačenje uglavnom je ograničeno na teorijsko obrazlaganje islamskog učenja u okviru Islamske zajednice i obrednu praksu hanefijskog mezheba.

- Period iza toga karakteriše trend zaustavljanja sekularizacije pravnih sistema muslimanskih zemalja sa zapaženim interesovanjem za reafirmisanje Šerijata, koji se iznova izučava, ne više samo kao historijski surogat nego kao pravni sistem interesantan i zanimljiv $u$ savremenom uporednom pravu. 
Zbog evolutivnog procesa i transformacije koja se historijski desila, i nepoznavanja izvornog Šerijata, česta je praksa nekih autora da Šerijat poistovjećuju sa tradicijom i običajima, odnosno sa običajnom obredoslovnom praksom hanefijskog mezheba, čime se, naravno, devalvira priroda autentičnog pravnog sistema koji posjeduje svoje izvore.

Evolutivni karakter nije samo proces slabljenja Šerijata u primjeni nego je omogućen jednim dijelom njegovom strukturom i prirodom šerijatskih izvora koja potiče evolutivne promjene reformama običajne prakse koja se mijenja, čime se, na izvjestan način amortizuje zastarjelost i sprečava ukidanje i potpuna zamjena šerijatskog sistema nekim drugim. Ovo svojstvo „konstantne", „nerevolucionarne" evolucije šerijatskih propisa u funkciji je dinamike i sadržaja šerijatske prakse.

Tome u prilog ide i činjenica da mudžtehid, kao pravni ekspert, u oblasti općih, nefiksiranih normi, vrši tumačenje, oblikovanje i donošenje propisa što rezultira da pravni sistem Šerijata, teoretski, ne ovisi o državi i državnim organima, te se može razvijati i prakticirati u bilo kojem sistemu, zavisno od modela demokratije, političkih i vjerskih sloboda. Zbog toga se po logici stvari i praktični Šerijat može održati u nešerijatskom pravnom poretku. Tako je uz određenu evolutivnu praksu i adaptaciju bilo i u BiH. Naravno, u ovom slučaju ne radi se o sadržaju šerijatske prakse kompletnog sistema Šerijata, jer postoji dio čija je praktična primjena u isključivoj jurisdikciji i nadležnosti države te se ne ostvaruje, osim u slučaju postojanja šerijatske vlasti.

Dakle, islam od početka u svojoj izvornoj osnovi baštini instrumentarij koji ga prilagođava i omogućuje njegov opstanak čak i $\mathrm{u}$ nešerijatskim pravnim porecima jer se derivacija šerijatske legislative uzima i iz promjenljivih, nekonstantnih šerijatskih izvora (u'rf i neki drugi nesamostalni izvori) što mu daje dinamiku i fleksibilnost. S druge strane praksa islama vezuje se za svaku osobu pojedinačno, za njegovu autonomiju ili heteronomiju volje, ličnu praksu i način življenja, te ne ovisi samo od islamske vlasti i države, koja ga u slučaju postojanja, naravno, štiti i kompletira, ali ne igra presudnu ulogu u njegovoj primjeni.

Ovo je logičko objašnjenje opstanka i sadržaja šerijatske prakse u vidu moralnog, etičkog kodeksa, ãdeta, običaja i tradicije, nakon povlačenja osmanske vlasti iz $\mathrm{BiH}$. 
Dakle, kod muslimana naših krajeva desilo se da je u jednom historijskom periodu efikasno, konstantno sukcesivno prakticiranje, posebno obredoslovne grane Šerijata, uslovilo u muslimanskom društvu nastajanje mnogobrojnih islamskih, šerijatskih običaja. Šerijat se jednostavno pretvorio u običaj (a'det) i kao takav uspio sačuvati od potpunog nestajanja iz pravne prakse. Naravno, nije to bio slučaj sa kompletnim sistemom Šerijata.

Tu se radi o tzv. Božijim hakkovima (dužnost prema Bogu) kao što su islamski ruknovi: šehadet, namaz, post, zekjat i hadždž.

$\mathrm{U}$ literarnom narodnom stvaralaštvu, narodnom blagu, narodnim pjesmama, dosjetkama, mudrostima itd. imamo bilježenje, deskripciju i verifikaciju tih običaja i običajne prakse muslimana $\mathrm{u}$ pojedinim mjestima $\mathrm{BiH}$.

Određeni pravni termini nisu spominjani u narodnom blagu osim kad je pravno ponašanje koje se njime iskazuje doista bilo $u$ dugotrajnoj običajnoj praksi naroda koji ga je onda memorisao $u$ svojoj kolektivnoj svijesti i izrazio kroz narodno stvaralaštvo.

Pošto je Šerijat obaveznog karaktera za sljedbenike, i pošto je vjera bit i svrha čovjekovog života kao što se razumije iz kur'anske norme:

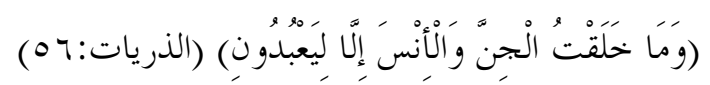

Džine i ljude sam stvorio samo zato da bi mi se klanjali /Ez-Zarijat:56/, onda su i običaji - u koje su se pretvorile mnogobrojne šerijatske norme tokom njegove historijske evolucije na našim prostorima - obavezni za primjenu, poštuju se i ne skrnave, kako konstatuje narodni pjesnik, „makar glava bila u pitanju”. To je razumljivo iz motiva narodnog pjesništva, a stihovi narodne pjesme „Đulić bajraktar Mustajbegov u Senju” to zorno ilustruju. Naime, Đulić bajraktar se u osam mejdana bori sa osam muških članova porodice Konjević, koji ga izazivaju na mejdan. U svakom od tih mejdana biva pogođen puškom i nanovo ranjen. Međutim, pošto je bilo nepisano pravilo/običaj da izazovu na mejdan, izazvani mora odgovoriti, pa Mustajbeg Lički, kao vođa muslimana, ne dozvoljava odmjenu izranjavanog Đulića:

U pjesmi se navodi da Dizdarević Meho želi zamijeniti izranjavanog bajraktara, ali mu Mustajbeg ne dozvoljava.

Krvav đogo po mejdanu skače,

Dok sta vika Dizdarević Meha: 
„A Mustaj-beg, direk od Udbine!

Pušćaj Meha i konja dorata,

Čudo j', beže, osam na jednoga?"

Viče glava bega udbinjskoga:

„Davor sine, Dizdarević Meho!

Adet nije izm'jeniti bajra,

Njega braća Konjevići viču;

Već za Boga i za dovu Turci!",

Običaj se, dakle, toliko poštovao da Mustajbeg ne dozvoljava izmjenu izranjavanog mejdandžije Đulića, čak ni svome bajraktaru Vrciću, koji na tome insistira:

„Pust' me, Lika, direk od Udbine,

da izm'jenim Đulić bajraktara."

Njemu veli sa goluba Lika:

„Deder stani, Vrcić bajraktare,

nije adet indat učiniti.

Dakle, ono što nije adet, tj. nije običaj da se čini i radi, ne smije se ni činiti makar bilo sa moralnog aspekta opravdano. Adet je jednostavno kult, transformisana vjera - Šerijat, čiji se prerogativi poštuju.

Običaji koje inače slijede pojedine grupe i narodi, kao program života, imaju kod njih poštovanje i utjecaj kojem se potčinjavaju, ponoseći se time i smatrajući da je to životna potreba bez koje se ne može.

Oni to ponekad dižu na stepen svetosti, vjere i obaveznog slijeđenja čije je napuštanje grijeh. Dakle, u slučaju muslimana, stavljaju to na stepen Serijata.

To se može i sociološki objasniti. Ljudska priroda se srodi sa običajima i tradicijom isto kao što se bujica srodi sa nizbrdicom niz koju ustali svoj put koji se ne može mijenjati bez stanovite teškoće. I kao što je teško mijenjati korito bujice, slične teškoće se susreću i kod promjene običaja.

Zato kažu: „Navika je druga priroda”, slična prirodi po kojoj je stvoren čovjek; ima ruke da radi njima, noge da hoda, oči da gleda, uši da sluša, pa kada bi pokušao promijeniti to tako da hoda na rukama, da radi nogama, da sluša očima, da gleda ušima - ne bi mu

${ }^{1}$ Kosta Hörmann, Junačke pjesme, Sarajevo, april 1889, 413.

${ }^{2}$ Ibid, 414. 
pošlo za rukom. Slično tome bi bio pokušaj promjene te „druge čovječije prirode" ili promjena tradicije, navike, adeta i običaja.

Zato islamski pravnici konstatuju: „Odvikavanje ljudi od njihovih običaja predstavlja haredž a'zim, tj. ogromnu, veliku teškoću". ${ }^{3}$

To se može uraditi samo silom ili postupno mukotrpnim odgojem i edukacijom.

Buharija $^{4}$ bilježi predanje od Aiše, r.a.:

„Prvo su objavljene sure koje su detaljno pojasnile pitanje dženneta i džehennema, a kada su ljudi ušli u islam, onda je objavljivano o halalu (dozvoljene stvari) i haramu (zabranjene stvari).

A da je prvo objavljeno: ,Ne pijte alkohol!' Rekli bi: ,Nikad ga nećemo ostaviti.' Ili da je objavljeno: ,Ne činite blud!' Rekli bi: ,Nikad ga se proći nećemo.",

Zato često kao daije, kao misionari, kao imami i hatibi, pravimo katastrofalne greške prvo napadajući i kritikujući ljude zbog njihovog neprakticiranja islama. Tako se izgubi povjerenje i stvori averzija a da prije toga nije pojašnjena vrijednost $i$ prednost originalnog islama, islama za koji, kada uđe u srce i grudi, više nema sile koja ga može istjerati iz te tvrđave.

Zbog ove snage koju posjeduje običaj, a posebno zbog teškoće koja se susreće u pokušaju njegove promjene kada se ustali, potrebno je da njegov nastanak kontroliraju islamski djelatnici, misionari, daije, pravnici, hodže, imami, hatibi, shodno instituciji ,naređivanja dobra a zabrane zla", tako da se spriječi nastanak ružnog i pokuđenog adeta, a da se eventualno stimuliše i podrži ustrojavanje na lijepim i korisnim islamskim, šerijatskim običajima.

Navešćemo lijep primjer iz narodne epike koji govori o nekim izuzetno značajnim običajima bosanskih muslimana nastali iz šerijatske, ibadetske prakse muslimana.

\footnotetext{
${ }^{3}$ Vidi: Ahmed Fehmi Ebu-Sunne, El-urfu vel-adetu fi re'jil-fuqahai (U'rf i a'det u mišljenju islamskih pravnika), IEIP, 1992, 20.

4 Vidi: Kitabu fedailil-Kur'an, babu te'lifil-Kur'an (Knjiga o vrijednostima Kur'ana, poglavlje o pisanju Kur'ana), hadis br. 4993.
} 
Selam, džematile-namaz i učenje djece u mejtefu

Prilikom službenih posjeta i susreta sa narodom, narodne vođe su se ranije, običajno, raspitivale upravo o vjerskoj praksi jer je vjera bila predmet najveće brige i poštovanja. Opće vjerske vrijednosti su prve o kojima se vodi briga. Odgovorni se pitaju za njihovo stanje i praktičnu primjenu kako se razumije iz pjesme „Dolazak bosanskog vezira Ćuprilića u Travnik".

Navešćemo nekoliko stihova iz ove pjesme koji će to zorno ilustrovati. Vrlo je zanimljiv opis susreta vezira ili hodže Ćuprilića sa Bosancima, njegovo protokolarno ponašanje i njegova mudra pitanja. Ćuprilija je predstavljen kao mudri, umni sultanov državni upravitelj ogromne Osmanske imperije, koja se rasprostirala na vrlo širokom teritoriju duboko zadirući i u evropski prostor.

Dakle, ovdje se radi o upravitelju tada svjetske sile te zato smatramo značajnim da znamo šta je taj upravitelj tadašnje svjetske sile smatrao važnim da se potencira i pita prilikom ovakvog jednog susreta i o čemu da se razgovara.

Sigurno je da su to i strateški važne stvari, odnosno ono što je najbitnije od bitnog i na osnovu čega će Ćuprilija shvatiti, kada dobije odgovore na svoja pitanja, u kakvom stanju je i ovaj dio carevine.

Mnogi će se, ne znajući istinske vrijednosti, iznenaditi onim o čemu se pita Ćuprilija. Naime, neće biti pitanja oko akciza, carina, niti oko poreza, vila, kula i gradova. Ali ono što je pitao mudri Ćuprilija može poslužiti kao paradigma oko koje možemo dobro porazmisliti.

Ćuprilija će prvo poselamiti sakupljene Bosance - Bošnjake.

A naljeze Ćuprilić-vezire.

Bošnjacima božji selam viknu,

Zatim se obraća Bosancima i onda slijede pitanja. Šta pita na prvom mjestu?

Tada vezir Bošnjacima zađe:

„Kako ste mi, moja djeco draga,

Klanjaju li Turci džematile,

Učite li vi djecu и mejtefu?

Pazi li se među sobom narod"5

${ }^{5}$ Kosta Hörmann, Narodne pjesme muslimana u Bosni i Hercegovini (priredila i predgovor napisala Đenana Buturović), Svjetlost, Sarajevo, 1990, 1, 88. 
Dakle, ovo su te bitne stvari vezane za sigurnost i opstanak Carevine a o kojima pita mudri Ćuprilija.

Slobodno možemo reći da je sve ovo i sada strateški važno za muslimane na ovim prostorima jer su dio njihovog historijskog i nacionalnog identiteta. To su elementi koji bi, kada bi se objedinili, kod muslimana predstavljali pozitivnu monolitnu platformu narodnog jedinstva.

I sada, kada bi se muslimani u međusobnom odnosu i korespodenciji selamili, kada bi se svakodnevno okupljali na zajedničke, džematile-namaze, kada bi se međusobno pazili onako kako je to uobičajeno među braćom po vjeri i ideologiji, onda bi sigurno bili monolitni i kompaktni i zajednički bi mogli rješavati sve nastale probleme i izazove. I one unutrašnje i vanjske.

Ako sada analiziramo aktualni politički trenutak, zapazićemo da je kod nas jedan od osnovnih problema nejedinstvo i međusobna suprotstavljenost, i na nivou džemata $\mathrm{i}$ općine i kantona i na nivou države, i to tolika da se to jednostavno ne može prevazići.

Da li to nejedinstvo istinski želimo prevazići?

Ako se pozitivno odgovori na pitanja koja je nekada davno postavio mudri Ćuprilić, onda se to može.

Ćuprilić pita Bošnjake, kako se razumije iz spomenute narodne pjesme, za osnovne stvari kroz koje se praktično, pojavno manifestuje vjerski suverenitet. To su pitanja:

- javnog, zajedničkog namaza kao vida veze muslimana sa svojim Gospodarem, organizovano mejtefsko poučavanje osnova vjere $\mathrm{i}$

- pitanje međusobnog korelacijskog odnosa muslimana unutar muslimanskog društva.

Zašto narodni pjesnik spominje i bilježi, u ovih nkoliko stihova, baš ove četiri vrijednosti:

1. selam, islamski pozdrav,

2. džematile-namaz,

3. učenje djece u mejtefu i

4. međusobne fine, islamske odnose u narodu?

Selam - islamski pozdrav

Ljudi se na različitim mjestima zemaljske kugle različito pozdravljaju. To pozdravljanje čini čitav jedan konglomerat riječi, 
fraza, pokreta, naklona, poklanjanja, preklona, klečanja i sl. Različite socijalne grupe, također, imaju svoje pozdrave koji se međusobno razlikuju.

U našem društvu, među mlađom populacijom, na ulici, $u$ radničkim sredinama, vojsci i sl., dakle gdje nema oštrije povučene granice između socijalnih grupa, pozdrav prilikom međusobnih susreta zna biti i najbanalnija psovka: psovka majke, sestre ili žene. Nerijetko čuješ nasred ulice da neko svom poznaniku dobacuje «da mu majku, sestru i sl.» pitajući ga uz to i «kako je»!

Najraprostranjeniji pozdravi u našoj sredini koji se sada mogu čuti jesu, ako izuzmemo selam, slijedeći pozdravi: „dobro jutro“, „dobar dan“, „dobra večer“, ,zdravo“; u novije vrijeme strani izrazi iz njemačkog i engleskog, posebno „ćus“, „ćao“ i sl.

Sve su ovo pozdravi bez nekog logičkog značenja. Čak i «dobro jutro» ili «dobar dan», iako imaju svoja začenja, ipak su samo jedan vid konstatacije bez korisnog, jasnog, upotrebnog značenja. Ne čujemo da neko bar kaže «dobar dan vam želim» i sl. što bi bar imalo nekakvog smisla i jezičkog značenja.

Nasuprot ovim uobičajenim pozdravima koje smo spomenuli, muslimanski ummet ima svoj originalni pozdrav, izuzetno lijepog značenja. To je selam, pozdrav sa kojim se pozdravlja na dunjaluku u svim geografskim sredinima, u svim socijalnim grupama i u svakom vremenu. Pozdrav je obilježje islama i njegove pripadnosti. A to će biti pozdrav sa kojim će se pozdravljati i u Džennetu.

Uzvišeni Allah kaže u suri «Ez-Zumer»:

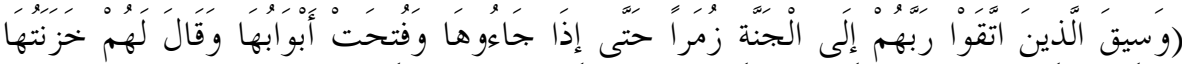

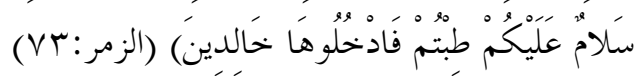

A oni koji su se Gospodara svoga bojali u povorkama će u Džennet biti povedeni, i kad do njega dođu, - a kapije njegove već širom otvorene - , čuvari njegovi će reći «Selam 'alejkum» od grijeha ste čisti, zato uđite u nj, u njemu ćete vječno boraviti. (EzZumer: 73)

I pored toga, islamski pozdrav - selam - kao da je predmet stida, nešto što je manje vrijedno od ostalih pozdrava, kao da je simbol zaostalosti kod nekakve kvazigospode i kvaziintelektualaca koji se samo površno osvrću na mnoge vrijednosti u muslimanskom etnološkom korpusu: vjerskog, običajnog, tradicijskog ili etnološkog karaktera. 
A ako analiziramo raniju praksu naših muslimana koja je zabilježena i verifikovana u narodnom stvaralaštvu, doći ćemo do rezultata da je selam (islamski pozdrav) nerazdvojni segment muslimanskog identiteta, običaj - tradicija koju su prakticirali svi. Naime, selam se nazivao u svim krugovima i kategorijama muslimanskog društva: od porodice i običnih ljudi do epskih junaka, vezīra i cara-sultana.

Za ovo imamo primjere u epskom stvaralaštvu i narodnoj epici koja je zabilježila vijekovima prakticirane običaje muslimana:

Ale Talu turski selam viknu,

A Tale mu selam prifatio. ${ }^{6}$

Kad Alija ugleda vezira,

...pa veziru selam nazivaše,

a vezir mu selam prifatio.

Pa uleće caru и odaju.

Selam nazva, poleće mu ruci. ${ }^{8}$

Selam nazva Ćuprilić vezire ${ }^{9}$, itd, itd.

$\mathrm{U}$ narodnom pjesništvu spominje se i odgovor na selam, kao u stihovima pjesme „Ibrahim-beg Ljubović”:

Bez̆e njemu turski selam viknu:

„Alejć selam, serhatlija mlada!"10

Sama riječ «selam» jedno je od «El-Esmaul-husna», tj. Allahovih lijepih imena i znači 'mir', 'spas'. U pozdravu znači 'neka si u Allahovom okrilju i zaštiti'. Ima li išta ljepše nego biti u zaštiti Gospodara svijeta?

Dakle, «selamom» se traži Allahova zaštita onoga koga pozdravljamo. I ako čovjek želi dobro, spas i selam onome koga pozdravlja, onda je sigurno da je to u funkciji voljenja i širenja ljubavi među ljudima, a to je ono što nam je nasušna potreba u ovoj državi i u ovom društvu.

Zbog toga nema mjesta stidu kod nazivanja selama.

6 Đenana Buturović, Antologija bošnjačke usmene epike, Izdavačka kuća Alef, Sarajevo, 1997, 582.

${ }^{7}$ Ibid, 582 .

8 Ibid, 576.

${ }^{9}$ Ibid, 577.

${ }^{10}$ Kosta Hörmann, Narodne pjesme muslimana u Bosni i Hercegovini (priredila i predgovor napisala Đenana Buturović), Svjetlost, Sarajevo, 1990, 1, 166. 
U najkraćoj verziji selam na arapskom jeziku glasi: „EsSelamu a'lejkum". Najkraća, zadovoljavajuća verzija odgovora je: „Ve a'lejkumus-Selam” ('Neka ste i vi u Allahovoj zaštiti').

Islamski učenjaci smatraju da se u odgovoru na selam obavezno treba izgovoriti veznik „vava” (ve), dok jedna grupa pravnika smatra da je to samo mendub (lijepo), a ne obaveza.

Najpotpunija verzija selama je „Es-Selamu a'lejkum ve rahmetullahi ve berekjatuhu" ('Neka je Allahovo ime/spas, mir/, Njegova milost i blagoslov na vas').

A najpotpuniji odgovor je „Ve a'lejkumus-Selamu ve rahmetullahi ve berekjatuhu" ('I neka je na vas Allahovo ime /spas, $\mathrm{mir} /$, Njegova milost i blagoslov').

Način da se ljudi zavole, da se riješe razjedinjenosti i neslaganja jeste da se selame, pozdravljaju selamom, islamskim pozdravom.

Poslanik, a.s., rekao je, a prenosi Ebu-Hurejre:

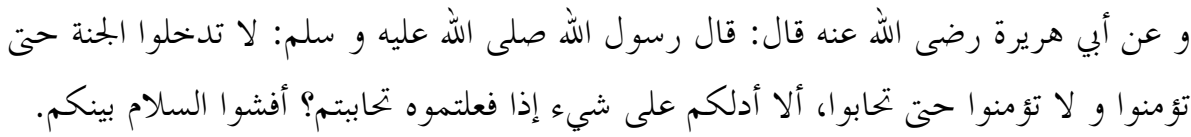

„Nećete ući u džennet dok ne budete vjerovali, niti ćete vjerovati dok se ne budete međusobno voljeli. A da vas uputim na praksu s kojom ćete se zavoljeti?!

Međusobno se pozdravljajte selamom i širite ga!" 11

Prema tome, selam je rješenje pa ako hoćete da se međusobno zavolite - vi u svojim kućama, porodicama, vi na ulici, vi u administraciji, vi u bolnici, vi u prosvjeti, vi u vojsci, vi u kompletnom društvu itd., itd. - onda se u pozdravljanju služite selamom.

Svjedoci smo da su najrasprostranjenije bolesti savremenog društva razne vrste stresova, bolestri srca i sl. Bolesti srca nastaju zavišću i mržnjom koja uništava čovjeka.

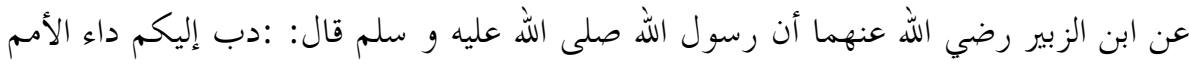

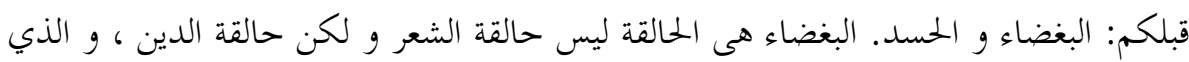

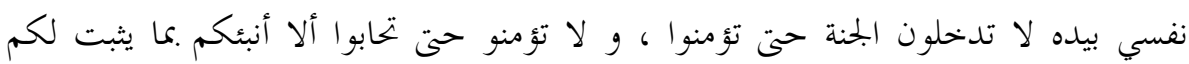

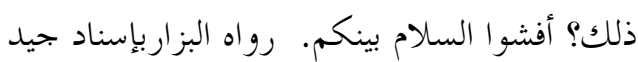

${ }^{11}$ Abdul-A'zim b. A'bdul-Kavvi El-Munziri, Et-Tergibu vet-terhibu minel-hadisiššerif (Stimuliranje i zastrašivanje kroz hadis Posalnika, a.s.), 3, 424. 
„Prenesene su vam, dolaze vam ili prikradaju vam se bolesti prijašnjih naroda: mržnja i zavist. Mržnja je kao brijač, ali koji ne brije kosu nego brije i ogoljava vjeru. Tako mi onoga u čijoj je ruci moja duša, nećete ući u džennet dok ne budete vjerovali, a nećete vjerovati dok se ne budete voljeli. Hoćete li da vam ukažem i da vas uputim na ono što će vam to utvrditi? Širite i nazivajte međusobno selam."

Bonton ili propisi vezani za islamsko pozdravljanje - selam sljedeći su ${ }^{12}$ :

U pravno-šerijatskom smislu nazivanje selama spada u kategoriju sunneta (sunnetska obaveza).

Odvraćanje selama je fardu a'jn (personalna obaveza) pojedinca kojemu se nazove i fardu kifaje (kolektivna obaveza) grupe, tj. ako neko iz grupe odvrati na selam, obaveza spada i sa ostalih.

U Kur'anu se kaže:

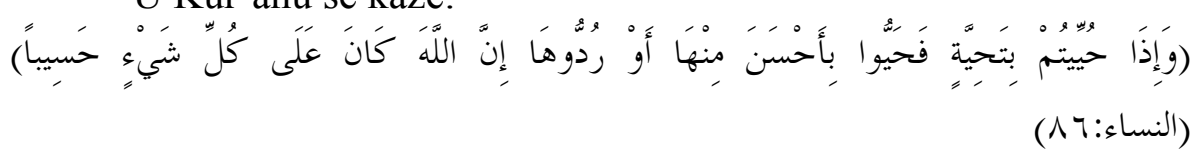

Kada pozdravom pozdravljeni budete, ljepšim od njega otpozdravite, ili ga uzvratite, jer će Allah za sve obračun tražiti. /En-Nisa:86/

U epskoj tradiciji imamo opisane slučajeve u kojima se ne odgovara na selam što je izraz i znak ljutnje na onoga koji ga naziva, što je motiv pjesme „Ibrahim-beg Ljubović”:

Beg veziru turski selam viknu,

vezir bega ni gledati neće,

a kamoli selam prihvatiti.

Tri puta mu selam nazivao,

vezir mu ga ne htje prihvatiti." 13

Takav slučaj je i u pjesmi „Pokajanje Mustaj-bega Ličkog”, gdje se Ćejvan-Djedo bezrazložno ljuti na Muju Hrnjicu, pa mu neće da odvrati na selam:

${ }^{12}$ Vidi: Dr. Vehbe Ez-Zuhajli, El-Fiqhul-islamijju ve edilletuh (Islamsko pravo i njegovi dokazi), Darul-fikr, 1996, 3, 577; Sejjid Sabik, Fikhus-sunne (Islamsko pravo u sunnetu), Darul-fikr, Bejrut, 1977, 3, 5; Abdul-A'zim b. A-bdul-Kavvi ElMunziri, Et-Tergibu vet-terhibu minel- hadisiš-šerif (Stimuliranje i zastrašivanje kroz hadis Posalnika, a.s.), 3, 432.

${ }^{13}$ Kosta Hörmann, Narodne pjesme muslimana u Bosni i Hercegovini (priredila i predgovor napisala Đenana Buturović), Svjetlost, Sarajevo, 1990, 1, 167. 


\section{Ćejvan-aga agam'govorio:}

„Nemojte mu selam prihvatiti!”

Serdar Mujo na odaju dođe,

Selam viknu turcim' na odaji.

Polako mu selam prihvatiše,

Ne šće stari selam prihvatiti,

Već serdaru leđa okrenuo.

Serdar njemu riječ govoraše:

„Ćejvan Djedo, prdě̌ino stara,

a šta sam ti učinio krivo,

te si meni leđa okrenuo., 14

Sličan je motiv i u pjesmi „Halil traži Mujova đogata”, samo što je Halil taj koji će iskusiti ljutnju starog Ćejvan-age:

\section{Halil pade mejhani na vrata,}

Pa agama turski selam viknu,

Sve su age selam prihvatile,

Al ne htjede Ćejvan-aga stari,

Već Halila krivo poglediva:

„Gdje s' Halile jedan hrsuzine? "15

Kad grupa otpočinje selam, to je sunnetu kifaje (sunnetska kolektivna obaveza), ali je vrednije da svako iz grupe nazove selam. Ako grupa nazove selam pojedincu, dozvoljeno je da on odvrati selam samo jednom kao odgovor svima.

Jahač ili onaj koji je u prevoznom sredstvu naziva selam pješaku. El-Bezzar i Ibni Hibban bilježe predanje od Džabira da je Poslanik, a.s, rekao: „Jahač naziva selam pješaku, pješak onome pored koga prolazi, a u susretu dva pješaka, ko otpočne sa selamom vredniji je."

Prilikom uobičajenog svakodnevnog susreta, selami se i rukuje, a po dolasku sa puta, zagrli se, kao što je došlo u hadisu Enesa koji bilježi Taberanija: „Ashabi Poslanika, a.s., su se prilikom susreta selamili i rukovali, a prilikom dolaska sa puta grlili.,"16

Ovi propisi opisuju se u praksi i tradiciji naših muslimana.

\footnotetext{
${ }^{14}$ Kosta Hörmann, Narodne pjesme muslimana u Bosni i Hercegovini (priredila i predgovor napisala Đenana Buturović), Svjetlost, Sarajevo, 1990, 1, 422.

${ }^{15}$ Kosta Hörmann, Junačke pjesme, Sarajevo, april 1889, 245.

16 Abdul-A'zim b. A-bdul-Kavvi El-Munziri, Et-Tergibu vet-terhibu minelhadisiš-šerif (Stimuliranje i zastrašivanje kroz hadis Posalnika, a.s.), 3, 433.
} 
U pjesmi „Hajduk Golalija i Arzulja arzuljskog bana” opisuje se susret Tala Ličanina i Alije nakon što se nisu vidjeli dugo vremena:

Ale Talu turski selam viknu,

A Tale mu selam prifatio,

Po selamu hošgeldiju viknu,

Hošgeldiju $i$ safađeldiju.

Pa priđoše jedan do drugoga.

Pa kako se brate zagrlišse,

Zagrliše pa se poljubiše,

Baš ko da su od jedne matere. ${ }^{17}$

Sunnet je selam nazvati povišenim glasom da se dobro čuje, a u slučaju da se upućuje grupi u kojoj ima spavača, da se nazove prigušenim glasom.

U slučaju da se susreće više puta sa istom osobom u kratkom vremenskom periodu, sunnet je svaki put nazvati selam zbog uopćene hadiske norme: „Međusobno se pozdravljajte selamom i širite ga!”

Selam se naziva čak i u slučaju da je onaj koji ga naziva siguran u to da mu neće biti uzvraćen. Selam se naziva i djeci kojoj nije obaveza da uzvrate, dok je obaveza odraslima da uzvrate na dječiji selam.

Pokuđeno je:

1. naklanjati se kod selama,

2. nazivati selam u kupatilima,

3. nazivati selam onome ko jede ili je zauzet borbom,

4. onome ko je zauzet učenjem Kur'ana ili njegovim slušanjem, zikrom, predavanjem, hutbom, vazom ili njihovim slušanjem,

5. onome ko je zauzet hadžskim obredom telbije,

6. onome ko uči ezan ili ikamet,

7. onome ko obavlja fiziološku potrebu kao i odgovor na selam u ovoj situaciji itd. (Naravno, onome ko naziva selam u ovakvim prilikama, ne mora se odgovoriti na njega.)

Sunnet je nazvati selam prilikom opraštanja od društva, prilikom ulaska u svoju kuću, svojoj porodici itd.

U pjesmi „Hajduk Golalija i Arzulja arzuljskog bana” Alija naziva selam svojoj majci:

17 Đenana Buturović, Antologija bošnjačke usmene epike, Izdavačka kuća Alef, Sarajevo, 1997, 582. 
Kad Aliju sina ugledala,

Kako skoči ostarila nana,

Ko da joj je sedamn'es godina.

Alija joj Božji selam viknu. ${ }^{18}$

A u pjesmi „Tale Ličanin u sužanjstvu” Halil Hrnjica naziva selam svojoj sestri kada dolazi kući. Ona mu uzvraća na selam:

Da vidimo gojenog Halila

Kud god ide na Kladušu side.

Dočeka ga sestra na avliji.

Kada Ajka opazi Halila

Ona bratu prifati gjogata

Pomože mu gjogu razjahati.

Halil Ajki turski selam viknu

A Ajka mu selam otprimila. ${ }^{19}$

Selam se naziva prije otpočinjanja bilo kakvog drugog govora jer je Poslanik, a.s., rekao: „Selam se naziva prije govora.”

Nije po bontonu kod selama i pozdravljanja da se klanja ili ustaje ispred ovosvjetskih veličina i autoriteta. Ebu Davud bilježi predanje od Mua'vije: „Ko voli da ljudi ispred njega ustaju, neka pripremi sebi mjesto u džehennemu (pakao).’

U poziciji rata $\mathrm{i}$ borbe ako neprijateljski vojnik nazove selam, trebalo bi ga poštedjeti i prestati sa napadom na njega (osim u slučaju da se radi o ratnoj varci).

U slučaju pozdrava kršćana ili židova odgovara se sa ,ve a'lejkum" ('i vama') kao što je došlo u predanju koje bilježe Buharija i Muslim.

Muslim, Ebu Davud i Tirmizija bilježe i predanje: „Ne otpočinjite pozdravljanje kršćana i Židova sa selamom."20

Molimo Uzvišenog Alaha da nam selam bude pozdravom na dunjaluku i ahiretu.

\footnotetext{
18 Ibid.

19 Esad Hadžiomerspahić, Muslimanske narodne junačke pjesme, S. Ugrenović, Banja Luka, 1909, 5.

${ }^{20}$ Abdul-A'zim b. A-bdul-Kavvi El-Munziri, Et-Tergibu vet-terhibu minel- hadisiššerif (Stimuliranje i zastrašivanje kroz hadis Posalnika, a.s.), 3, 435.
} 


\section{Džematile-namaz}

U daljnjem obraćanju, poslije selama, Ćuprilić prvo pita za praksu džematile-namaza kod Bošnjaka:

\section{Klanjaju li Turci džematile?}

Naravno, odgovor Ćupriliću je bio pozitivan: „Svi klanjamo dobro ď̈ematile", jer se osnovne vjerske obaveze zajedničkog klanjanja masovno primjenjuju kako je zabilježio narodni pjesnik u pjesmi „Urodila b’jelica šenica”:

Urodila b'jelica šenica,

Od Ponora do Vilića dvora.

Želo ju je trista žetelica,

A vezalo dvjesta vezioca,

I pred njima Ale Meuniću.

Kad su bili dvoru na avliju,

Večeraše i akšam klanjašse. ${ }^{21}$

U muslimanskim mjestima treba da se čuje učenje ezana, da se namaz klanja zajednički u džamiji, što je od vidljivih islamskih obilježja koja prave razliku između daru-islama i daru-kufura, odnosno, između muslimanskog i nemuslimanskog mjesta i zemlje. Omer b. El-Hattab pisao je svojim službenicima i namjesnicima: „Najbitnija vam je stvar, kod mene, namaz! Ko ga čuva i sačuva, sačuvao je vjeru. Ko ga upropasti, pogotovo će upropastiti druge važne obaveze.“

Što se tiče zajedničkog, džematile-namaza, kako razumjesmo iz spomenutog motiva narodne pjesme, njegova je primjena ranije bila masovna, običajna pojava kod muslimanskog društva.

A Ebu Hurejre, r.a., prenosi predanje, hadis koji bilježe Buharija, Muslim, Ebu Davud, Tirmizija i Ibnu Madždže: „Čovjekov namaz u džematu je vredniji za dvadeset i pet puta od njegova namaza kod kuće, ili u čaršiji. To se postiže ako čovjek uzme lijepo abdest, potom uputi u džamiju samo radi tog namaza. U tom slučaju neće napraviti korak a da mu njime ne bude podignut stepen - deredža i otklonjen neki grijeh. Kada klanja, meleki će, sve dok je na mjestu obavljanja namaza i dok ne izgubi abdest, donositi na njega salavat, govoreći: ,Gospodaru, neka je Tvoj salavat na njega. (Smiluj mu se i

21 Munib Maglajlić, Antologija bošnjačke usmene lirike, Izdavačka kuća Alef, Sarajevo, 1997, 160. 
podaj bereket). Smiluj se Ti, Gospodaru, njemu.' Tretira se da je u namazu sve dok iščekuje namaz."

Ahmed, Ebu Davud, Nesaija, Ibnu Huzejme i Hakim bilježe da je Ebud-Darda' čuo Allahovog Poslanika, a.s., da kaže: „Ako se nađu (makar) trojica u naseljenom mjestu ili nenaseljenom, pa ne budu zajednički obavljali namaz, šejtan (sotona) će ih opčiniti i staviti pod svoju kontrolu. Držite se džemata (grupa, društvo) jer se vuk obrušava na odvojenu ovcu koju pojede."

Ruzin dodaje u verziji svoga predanja još i ovaj dio:

$$
\text { الشيطان ذئب الإنسان إذا خلا به أكله }
$$

„Šejtan je čovjekov vuk. Ako se osami sa njim, pojede ga.”

$\mathrm{Na}$ temelju stimulirajućih hadiskih normi i drugih, strogih, koje straše i prijete onima koji se ne pridržavaju zajedničkog namaza, zaključujemo da nije čudno da u muslimanskom društvu čak i vladari, zajedno sa najvišim državnim službenicima, prakticiraju džematilenamaz, kako se spominje u narodnom pjesništvu:

Dok zauči pet stotin' ezana,

na pet stotin'bijelije munara.

Avdes uze care od Stambola,

pa on rano ode u džamiju.

Sabah klanja pa se bră̌e vrati. ${ }^{22}$

Dakle i sam car tada najveće svjetske sile ide na sabah u džamiju, također, njegov ministar, upravitelj carevine Ćuprilić, te junak mejdandžija Halil Hrnjica. U pjesmi se kazuje:

\section{Pa ga care dade Ćupriliću.}

\section{Otlen ode vezir sa Halilom}

u džamiju, te sabah klanjašse. ${ }^{23}$

Najvredniji zajednički namazi su sabah, jacija, pa ikindija, osim džume koja se inače obavlja samo zajednički u džematu.

Sabah i jacija su najvredniji zbog toga što hadiski autoriteti, izuzev Buharije i Tirmizije, bilježe predanje hadisa od Osmana b. Affana, r.a., koji je čuo Allahovog Poslanika, a.s., da kaže: „Ko klanja jaciju u džematu tretira se kao da je (dobrovoljno) klanjao pola noći, a onaj ko klanja sabah u džematu kao da je čitavu noć proveo u namazu."

${ }^{22}$ Đenana Buturović, Antologija bošnjačke usmene epike, Izdavačka kuća Alef, Sarajevo, 1997, 540.

${ }^{23}$ Isto, 241. 
Ova dva namaza su spomenuta kao najteži za obavljanje munaficima (licemjerima).

Ebu Hurejre, r.a., prenosi a Buharija i Muslim bilježe:

„Najteži namazi za munafike su namaz jacije i namaz sabaha. A da znaju kakva se vrijednost krije u njima, posjećivali bi ih makar puzeći..."

Muslimova verzija je još: bi."

„a da zna da će dobiti kakvu dobru komadesnicu mesa, došao

El-Munziri navodi predanje od Ibnu Omera, r.a., koje inače bilježe Taberanija i Ibnu Huzejme u svome Sahihu:

„Ashabi, ako ne bi susretali čovjeka (u džamiji) prilikom namaza jacije i sabaha, o njemu bi imali loše mišljenje."

Musliman bi svoj radni dan trebao započinjati sa sabahom u džamiji i završavati sa jacijom tako da sav njegov život bude negdje u ambijentu džamije. bolesti.

Poslanik, a.s., nije ostavljao džematile-namaz čak ni u smrtnoj

Omer, r.a., uboden je u džamiji na sabah-namazu. Dok je još bio pri svijesti, prije nego je pao u nesvijest, povukao je najbližeg ashaba da završi sa džematile-namazom. Nije zajaukao, zavrištao i prekinuo džematile-namaz iako je bio smrtno uboden.

Prenosi se, također, da je jedan iz generacije selefus-salihina naredio svojoj djeci - bolestan, nepokretan, u smrtnoj bolesti - čuvši riječi ezana (,Dođi na namaz, dođi na spas“): „Nosite me u džamiju!"

Rekoše mu: „Pa ti si bolestan. Ti imaš uzur, opravdanje. Ti ne moraš ići u džamiju."

A on odvrati: „La ilahe illellah! Čujem ezan i poziv za namaz pa da ne odgovorim."

Odnesoše ga u džamiju. I na jednoj sedždi je preselio. Smrt je najteži momenat koji će se doživjeti na ovom dunjaluku. On je taj teški momenat koji kod mnogih traje danima, mjesecima i godinama pa umiru, a umrijeti ne mogu; raspadaju se, a duša izaći ne može dok ne dođe određeni trenutak. On je taj momenat doživio gotovo neosjetno, zato što je bio na sedždi, u audijenciji pred Allahom, poštujući Njegovu naredbu pa je i melek smrti to uvažio prevodeći ga sa dunjaluka na ahiret na tako bezbolan način.

Kaže Se'id b. El-Musejjeb: 
„Ništa od svojih poslova, poslije šehadeta: la ilahe illellah ne volim kao to što mi četrdeset godina nije promakao početni tekbir u džematile namazu." El-E'ameš kaže „šezdeset godina".

Četrdeset ili šezdeset godina stalnog, konstantnog bdijenja nad džematile- namazom!!!

Onaj ko izgubi džematile-namaz bez opravdanog razloga, gubi Allahovo svjetlo vodilju i Njegovu uputu.

Svi mi imamo greški u pogledu džematile-namaza, i oni koji ga obavljaju i oni koji ga zanemaruju. Oni koji ga obavljaju zanemaruju pozvati i druge.

Kako će se odgojiti generacija novih muslimana ako ne pune džamiju? Kako će se spasiti mladić, musliman od droge i od ostalih poroka ako se ne zaštiti džamijom i džematile-namazom?!

Musliman koji klanja sabah ima i poseban stepen i čast kod narodnog pjesnika - što je motiv pjesme „Kad umrije srma Ibrahime":

Kad umrije srma Ibrahime,

u džamiji sabah klanjajući:

nit' je sklanjo, nit' selama dao,

već umrije, žalosna mu majka!

Njega žali i staro i mlado,

I sokaci kud je prolazio,

I pendžeri đe je dolazio:

Svi sokaci travicom porasli,

A pendžeri prahom popanuli. ${ }^{24}$

U sličnom značenju je predanje, hadis Šurejha Hadramija u kojem se kaže:

„Vjernik nikad nije stranac. Niti će umrijeti bez onih koji ga žale. Za njim plaču nebo i Zemlja. Potom je Allahov Poslanik, a.s, proučio ajet: ,Ni nebo ih ni Zemlja nisu oplakivali, i nisu pošteđeni bili ${ }^{25}$, a zatim dodao: 'Ovo dvoje ne plače za nevjernikom.", ${ }^{26}$

Islam se temelji na pet temelja/ruknova. To su, terminološki, sastavni dijelovi bez kojih nema islama. Međutim, ostali ruknovi,

24 Munib Maglajlić, Antologija bošnjačke usmene lirike, Izdavačka kuća Alef, Sarajevo, 1997, 185.

${ }^{25}$ Kur'an, 44, 29.

${ }^{26}$ Muhammed Nesib Er-Rifa'i, Tejsirul-Alijjil-kadir lihtisari tefsir Ibn Kesir (Olakšavanje Uzvišenog-Moćnog u sižeiranju komentara Ibn Kesira), Bejrut, 1978, 4, 150 . 
izuzev namaza, ne moraju uvijek i u svakoj prilici da budu prisutni $\mathrm{u}$ praksi svakog muslimana. Naime, ima siromašnih muslimana koji ne moraju ići na hadždž, nisu obavezni dijeliti zekjat i sl. Ima ih bolesnih, iznemoglih, putnika i slično, pa ne moraju u tim (ne)prilikama postiti, itd.

Dakle, spomenuti ruknovi islama ne moraju uvijek biti u praksi svih muslimana, nego samo kad se ispune uvjeti za njihovo izvršenje kod svakog obveznika pojedinačno.

Međutim, u islamu mora biti nešto što će svakog muslimana, uvijek, u svakoj prilici identifikovati i determinirati kao vjernika, praktičara. Tu ulogu ima samo namaz. Ovu specifičnost nema ni jedan drugi rukn i stub islama.

Namaz je vid praktične lične iskaznice muslimana ${ }^{27}$, legitimacija kojom on dokazuje svoj vjernički identitet uvijek, u svakoj prilici i obavezno pet puta na dan: kada je kod kuće ili na putu, u miru ili ratu - borbi, kada je slobodan ili zaposlen, zdrav ili bolestan. Naravno, uz to imaju olakšice za obavljanje namaza u raznim (ne)prilikama, kao što je skraćivanje četverorekjatnih namaza na dvorekjatne za putnika, mesh po mestvama i čarapama, tejemmum i sl.

Sa svojim specifičnostima i odlikama namaz se ne smije ostaviti i ne klanjati, jer to dovodi u pitanje kompletnu vjeru.

U Kur'anu se kaže:

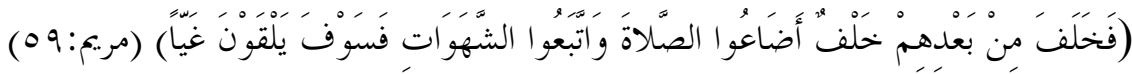

A njih smijeniše zli potomci, koji namaz upropastiše (napustiše) i za požudama pođoše; oni će sigurno zlo proći. /Merjem: 59/

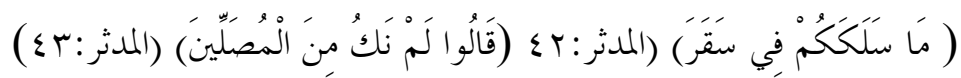

Šta vas je dovelo u Sekar (džehennem). Rekoše: Klanjači nismo bili.../El-Muddesir: 42-43/

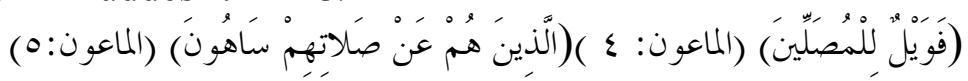

Teško onima koji, kad namaz obavljaju, molitvu svoju kako treba ne izvršavaju. /El-Ma'un:5/

\footnotetext{
${ }^{27}$ Naravno, ovdje se misli na muslimana kao pripadnika islamske vjeroispovijesti, a ne na muslimana nacionalno.
} 
U predanjima, koja govore o noći Isra'a i propisivanju namaza, spominje se da je Poslanik, a.s., vraćajući se te noći kroz nebeske sfere, doživio i to da vidi način eshatološkog kažnjavanja onih koji budu ostavljali namaz. Bilježi El-Bezzar, a prenosi Ebu Hurejre, r.a., „da je on (u noći Isra'a) došao do jedne skupine ljudi čije glave se razbijaju udarcem kamenčine, pa kad god se razbiju, budu povraćene u prvobitno stanje. Ta kazna se konstantno ponavlja. Poslanik, a.s., je upitao: ,Džibrile, ko su ovi?' On odgovori: ,To su oni kojima je bilo teško saginjati glavu i klanjati namaz.'"

Zastrašujuća je kazna koja se očituje u konstantnom razbijanju i zacjeljivanju glave a koja je rezultirala nemarnim odnosom prema namazu i njegovim izostavljanjem kao jedinstvenog, posebnog, specifičnog ibadeta.

Eš-Ša'ravi ovaj vid kazne tumači ovom logikom: u glavi nastaju izmišljeni razlozi i razna „opravdanja” za izostavljanje namaza, pa je stoga, figurativno rečeno, glava i pravi „krivac” za neobavljanje namaza. Ona treba da snosi i posljedice. Jer, bilo kakvo njeno opravdanje slabo je i nedostatno zato što postoje propisani načini obavljanja namaza u svakoj životnoj prilici i neprilici, a svaki taj način uvažava čovjekove psihofizičke mogućnosti. Zato nema opravdanja za ostavljanje namaza, pa otuda i takva kazna.

Islamsko poimanje svrhe i cilja bivstvovanja insana/čovjeka na ovom dunjaluku vezuje se za svekoliko praktično iskazivanje pokornosti Allahu, dž.s.s, kroz razne oblike obredoslovne prakse.

1. Namaz, tj. obredoslovna molitva, u samom je fokusu ibadetske piramide koja ne može stajati bez namaskog centralnog stuba. Ahmed, Tirmizija i Ibn Madždže bilježe vjerodostojno predanje u kojem Poslanik, a.s., kaže da je glava svih stvari islam, a stub islama namaz. Taberanija, jedan od hadiskih autoriteta, bilježi predanje u kojem se proklamuje da nema vjere onaj ko nema namaza, i da je status namaza u vjeri isto kao i glave na tijelu.

2. Namaz je u historiji šerijatskog zakonodavstva prvi propisani, naređeni ibadet koji je Zakonodavac propisao, u noći Mi'radž $a^{28}$, direktnom naredbom Poslaniku, a.s. Svi drugi ibadeti i sve druge naredbe i propisi došli su posredno objavom, preko meleka Džibrila, a.s.

28 Mi’radž je Uznesenje Poslanika, a.s., kroz nebeske sfere ka primordijalnom odredištu do kojeg nije doprlo ni jedno drugo stvorenje prije, niti poslije njega. 
Enes prenosi, a Ahmed, Nesaija i Tirmizija, koji ovo predanje smatra vjerodostojnim, bilježe da je u noći Mi'radža Muhammedu, a.s., propisano prvo pedeset (dnevnih) namaza. Nakon toga je smanjeno do granice od pet dnevnih namaza, a potom oglašeno da će nagrada za njih biti kao za pedeset.

3. Eshatološki gledano, na Sudnjem danu prvo će biti pitano za namaz, kako se razumije iz hadiskih normi. To je vid prijemnog, ali i konačnog ispita vjernika praktičara. Poslanik, a.s., rekao je, a Taberanija zabilježio: „Namaz je prvo za šta će Allahov rob polagati račun na Sudnjem danu. Ako položi taj ispit, moći će položiti i ostale. A ako na tom ispitu padne, propašće mu i ostala djela."

4. Ebu Ja'la bilježi predanje u kojemu se, između ostalog, navodi da će se sa dobrovoljnim namazima upotpunjavati propusti i nedostaci obaveznih namaza.

5. Posljednja oporuka Poslanika, a.s, bila je da se pazi i praktikuje namaz.

6. Ebu-Umame je prenio a Ibnu-Hibban zabilježio predanje: „Islamska praksa će se dio po dio gubiti. Kad god nestane iz prakse neka karika islama, ljudi će se pridržavati slijedeće. Prvo će nestati islamska vlast, a zadnji će se izgubiti namaz."

Iz svih navedenih tekstualnih primjera vidimo kakav značaj se pridaje namazu u vjerskim izvorima. Prakticiranje namaza je, dakle, prešlo u običaj i tradiciju muslimana.

\section{Mejtef}

Ne bih htio propustiti priliku a da ne ukažem i na još jednu veoma bitnu stvar o kojoj naš vezir Ćuprilić pita Bošnjake, a što je zabilježio narodni pjesnik. Naime, on pita:

\section{Uče li vi djeca u mejtefe?}

Pazi li se medu sobom narod"29

Učenje djece u mejtefu ili tzv. vjerska pouka djece po mejtefima kao i vjeronauka u školama strateško je pitanje muslimana na ovim prostorima.

$\mathrm{Na}$ ljeto se tradicionalno sumiraju rezultati te pouke kroz običajne manifestacije hatmenskih dova i džematske svečanosti.

${ }^{29}$ Kosta Hörmann, Narodne pjesme muslimana u Bosni i Hercegovini (priredila i predgovor napisala Đenana Buturović), Svijetlost, Sarajevo, 1990, 1, 88. 
Koliko je to bilo značajno za našu tradiciju i običaje, može se razumjeti iz stihova narodne epike. Posebno su egzemplarni stihovi koji sublimiraju značaj mejtefa i vjerske pouke $u$ jednoj narodnoj pjesmi gdje se daje opis Ibrahimbega koga svezana vode na vješanje a on se i u toj bezizlaznoj situaciji brine o odgoju svoje djece koja ostaju iza njega i trebala bi ići u mejtef da nauče osnove vjere. U stihovima te pjesme kaže se:

Ibrahim-bega svezana vode, svezana vode, da ga objese.

Ibrahim-beg se natrag obzire: „Ima l' ikoga od roda moga?" Za njim iđaše bratac Alija. „Alija, brate, pazi mi djecu, pazi mi moju, baš ko i svoju: kad svoju djecu u mejtef dadneš, Alija, brate, podaj i moju!"

Djeca u islamu nisu mukellefini ili, kako se to kaže u pravnoj terminologiji, nisu obveznici, adresati. Ne moraju izvršavati šerijatske obaveze sve dok ne postanu punoljetni. Pa ipak, u narodnoj epici je njihov status mejtefske djece dovoljan, bez ikakvih drugih djela, da se spominju kao stanovnici dženneta u društvu sa najpribranijim kategorijama džennetlija, što upućuje na visok stepen pribranosti kod Boga onih koji uče o vjeri, po kriteriju narodnog pjesnika, kao što se razumije iz više verzija pjesme „Kad ja pođo' u džamiju”:

Ja pogleda' po džennetu, po džennetu po devletu, ja ugleda' tri alaja: jedan alaj sve šehita, drugi alaj sve haď̌ija, treći alaj sitne dice, sitne dice iz mejtefa. ${ }^{31}$ $U$ džennetu jedno vrilo, tudi side tri buljuga: jedan buljug sve šehita, drugi buljug sve gazija,

${ }^{30}$ Munib Maglajlić, Antologija bošnjačke usmene lirike, Izdavačka kuća Alef, Sarajevo, 193.

${ }^{31}$ Alija Nametak, Od bešike do motike, Sarajevo, 1970, 17. 


\section{treći buljug sitne dice, \\ sitne dice iz, mejtafa."32}

Sjećajući se naše lijepe mejtefske tradicije i svečanosti povodom hatmi, o kojima se redovno izvještava $\mathrm{u}$ islamskim informativnim novinama „Preporod" a koje se svake godine organizuju po mnogim džematima širom naše Bosne, i sjećajući se vjeronauke po školama, uputio bih apel svim muslimanima, vjeroučiteljima, imamima i drugima da ljubomorno čuvaju i održavaju ovu tradiciju - tradiciju mejtefa i vjerske pouke, da joj posvete najveću moguću pažnju i da budnim okom paze da joj neko ne priprema neko zlo jer je vjeronauka od strateške važnosti za očuvanje našeg islamskog identiteta. Mudri Ćuprilić je to dobro znao pitajući Bošnjake:

\section{Učite li vi djecu u mejtefu?}

\section{Pazi li se medu sobom narod"33}

Brzina prolaznosti iznenadi. Čovjek se samo osvijesti i vidi da je na kraju puta. Pred smrću. A sve stvoreno će nestati i umrijeti. Čak i meleki, odabrana duhovna Allahova bića će poumirati kao što umiru ljudi i džini. Posljednji Allahov stvor koji će umrijeti jeste melek smrti. Prenosi se predanje da će Uzvišeni Allah upitati nakon što melek smrti usmrti i posljednje odabrane meleke Israfila i Mikaila:

- Ko je još ostao od mojih stvorenja?

Melek smrti će podnijeti zadnji izvještaj:

- Niko, osim Tvoga stvora koji je pred Tobom.

Onda će Uzvišeni narediti:

- O meleku smrti, umri i ti.

Kada i on umre i preseli, reći će Uzvišenom:

- Tako mi Tvoje veličanstvenosti i veličine, da sam znao da su smrtne muke ovako teške, molio bih Te (na Dunjaluku) da me poštediš zadatka uzimanja duša Tvojih robova.

Nakon smrti i posljednjeg stvora, meleka smrti, Uzvišeni Allah će zagrmiti na dunjaluk:

$$
\text { يا دنيا أين قصورك، يا دنيا أين أشجارك، أهارك، جبالك، بخومك؟ }
$$

- Dunjaluče, gdje su ti dvorci, gdje ti je drveće, gdje su ti rijeke, gdje su ti brda i zvijezde?

\footnotetext{
32 Ibid, 22.

${ }^{33}$ Kosta Hörmann, Narodne pjesme muslimana u Bosni i Hercegovini (priredila i predgovor napisala Đenana Buturović), Svijetlost, Sarajevo, 1990, 1, 88.
} 
Pitaće o mrtvoj prirodi. A zatim i o stvorenjima koja su imala život:

$$
\text { أين الجبابرة ، أين الذين عاشوا في خيري و عبدوا غيري؟ }
$$

- Gdje su oholnici, oni koji su živjeli u dobru i blagostanju koje sam im dao obožavajući druge osim Mene?

Biće to pitanje o upotrebi Allahovih ni'meta koje nam je dao da se njima služimo na ovome svijetu. Te blagodati su mnogobrojne. Neprocjenljive vrijednosti. Ko bi samo prodao jedno oko? Nos, ruku? Nogu? Itd.

Međutim i pored tih blagodati mnogi ljudi su se zaboravili pa su ih koristili a nisu se zahvaljivali na njima istinskom Bogu. Umjesto da Njega obožavaju, zalutali su i, koje li nesreće, umjesto Stvoritelja, obožavali su stvoreno, materijalni svijet. Obožavali su plažu, imetak, auta, žene, ljude.

Zatim će Uzvišeni Gospodar tri puta zapitati, citirajući pitanje koje je objavio u Kur'anu, o suri Gafir:

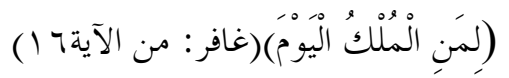

Čija vlast je danas? Ko je istinski vladar danas? /Gafir:16/

Toga dana neće biti nikog živog da bi odgovorio. Zatim će Uzvišeni sam sebi odgovoriti ajetom koji je nama ljudima objavio u suri Gafir ili El-mu'min:

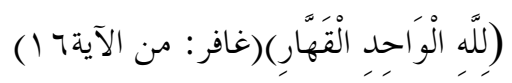

Pripada Allahu, Jedinom i Svemoćnom! /Gafir:16/

Dakle, sjećajući se svega ovoga ne možemo a da se ne sjetimo i naše lične, personalne prolaznosti na koju Kur'an podsjeća:

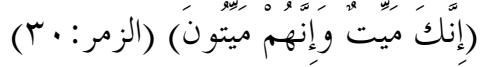

Ti ćeš, zacijelo, umrijeti, a i oni će, takođe, pomrijeti. /EzZumer:30/

Zbog ove prolaznosti, i zbog činjenice da ćemo se obreti pred smrću, najtežem trenutku u našem životu, postavljamo pitanje o svrsi života. Šta je to što treba raditi da bi se sa smirenošću dočekao taj najteži dan na dunjaluku?!

Islamski ummet - pravi muslimani znaju odgovor na ovo pitanje. Oni su shvatili filozofiju života, bit i svrhu postojanja na dunjaluku. Shvatili su vjeru i vrijednost vjere. A vjeri smo potrebniji nego bilo čemu drugom, potrebniji nego zraku koji udišemo jer će 
doći dan kada više nećemo - ma kako svježe bilo - moći ni jednom udahnuti; hrani koju jedemo jer će doći dan kada - ma kako hrana ukusna bila - nećemo više moći ništa progutati; vodi ili piću koje pijemo jer će doći dan kada - ma kako piće pitko bilo - nećemo moći ništa popiti.

Toga dana jedino što će koristiti jeste vjera i vjerska praksa.

Naši stari bili su svjesni toga. Zato je njihova vjerska praksa bila toliko učestala i konstantna da je ušla u običaj i tradiciju o kojoj smo imali priliku saznati informaciju više i okoristiti se time i kroz ovaj rad. 
DOC. DR. MUHAREM ŠTULANOVIĆ, SENIOR LECTURER

\section{ANALITICAL STUDY ABOUT HISTORICAL AND PRACTICAL TRANSFORMATION OF SHARIA'H INTO SHARIA'H CUSTOMS AND TRADITION}

SUMMARY

In the example of Muslims in our region in one historical period, effective, constant and successive practising of Islamic rules caused these rules to gradually become sharia'h customs. Sharia'h simply became custom and as such was adapted to "turbulent times» and saved from vanishing from practice. Certainly it was not the case with the complete sharia'h, but only with so called "rights of God» (duties towards God) - Islamic postulates: bearing witness that there is no other god but Allah, prayer, fasting, obligatory charity and pilgrimage.

In literal tradition, folk songs, proverbs and sayings there is registering, description and verification of these customs that were practised in certain places in BiH.

Since sharia'h is obligatory for its followers and religion is essence and aim of man's life as understood from qur'anic creed: "I have created jinni and humans only to worship me», then are the customs as well that came into being by transformation of sharia'h rules in the course of history in our region. People respect and don't violate these rules, as said by the poet: "even if it is the matter of life and death».

Islamic ummah - real Muslims know the answer to question on purpose of life. They understood philosophy of life, their aim of existence in this world. They understood religion and its value. Therefore their religious practice was often and constant and became custom and tradition which we were introduced to through this work. 


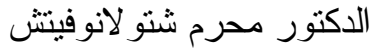

\section{دراسة تحليلية حول تحولات تاريخية وعملية للثريعة الإسلامية}

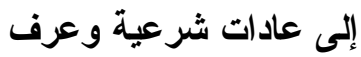

الملخص

لقد كان المسلمون في بلادنا في فترة من فترات يطبقون الإسلام بشكل فعال وشامل،

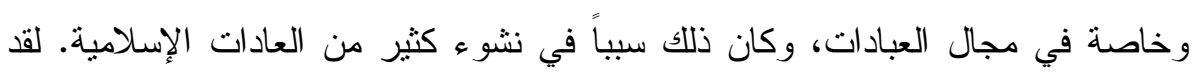

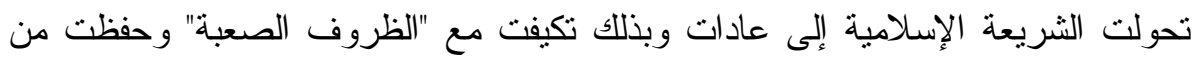
الزو ال في مجال النطبيق.

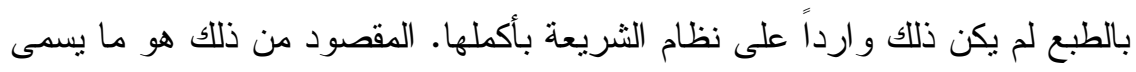

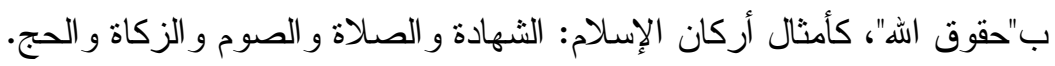

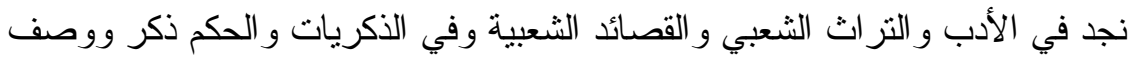
وتسجيل تلك العادات و العرف العملي لمسلمي بعض مناطق البوسنة و الهرسك.

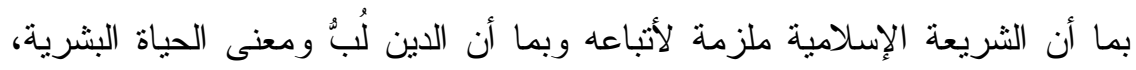

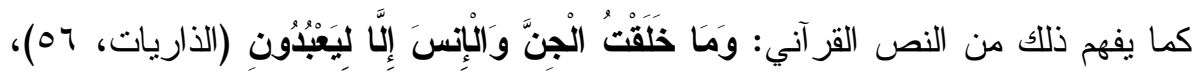

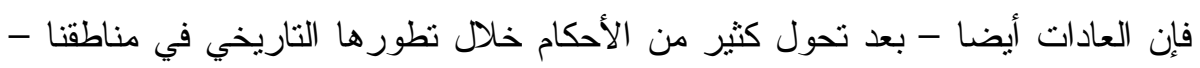

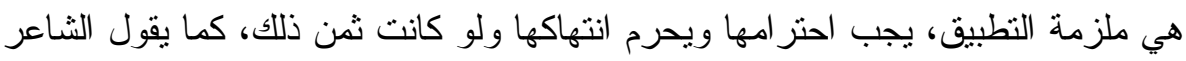
الشعبي، الحياة نفسها. الأمة الإسلامية و المسلمون الملتزمون حقيقةً يعرفون الإجابة على سؤ ال حول معنى

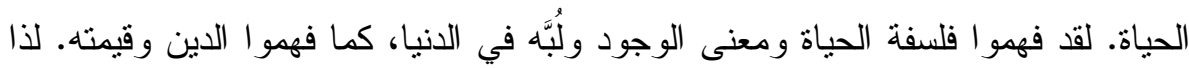

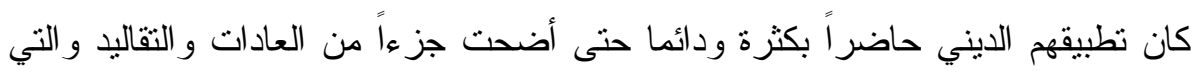

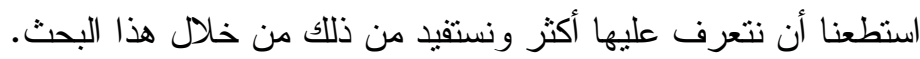

